\title{
Mr. Justice Holmes: The Community vs. The Individual
}

\author{
Walker Lowry*
}

More than any lawyer of the twentieth century Holmes captures the imagination. He is, in a praiseworthy sense, all things to all people. To the iconoclast, he is the great dissenter; to the liberal, he is the hero of the rebellion against judicial arrogance; to the conservative, a New England Yankee skeptical of economic nostrums; to the soldier, an apostle of war; to the philosopher, a gifted amateur honoring ideas above worldly accoinplishment; to the jurist, an inexhaustible source of wisdom and quotation; to the professor, a tireless student of legal history and legal purposes.

The resolution of this complexity is the work of biography and history. The lawyer has a different task. He must understand Holmes law. For in all the paradoxes of Holmes, the final paradox is that the Justice, now fifteen years resigned from the bench, has today greater influence than he ever exercised as the senior side judge. In many areas the present Court can differ with Holmes only by an obvious effort of will. Nor is this unnatural. Many of the Court members participated personally in the struggle agaimst the judges who for two decades denied the will of the people. Holmes was the hero of that struggle. To make his philosophy the law of the land was its prime purpose. Small wonder then that disagreement with Holmes now seems faintly akin to treason.

Whoever reads Holmes rapidly learns that it is easier to tabulate his ideas than to discover the source of his principles. He reached the Court at sixty-one with full maturity and after more than two decades on the Massachusetts bench. He was completely sophisticated in the judicial techmique. Almost immediately he announced the constitutional doctrine which he was to expound for thirty years. ${ }^{1}$ His statement, furthermore, was fully developed. The early opinions show little hesitation or uncertainty. Holmes, like Marshall, knew what he thought from the very beginning.

*L.L.B. Harvard University, 1935; nuember of the Cahfornia Bar and Bar of the United States. Supreme Court.

1 Otis v. Parker (1903) 187 U.S. 606. 
What was the source of this doctrine? Not, certainly, his work on the Massachusetts bench. The state decisions foreshadow the Supreme Court opinions but the foreshadowing is of a mind already resolved. The state opinions illustrate more than they explain the Holmes position.

Birth and training are scarcely more illuminating. Holnes, born only less than an Adams, was from beginning to end an aristocrat. His feelings and preferences were those of his class. But when his associates set out to make the dogmas of aristocracy into the law of the land, Holmes dissented with a vigor unmatched in American judicial history. Why?

Probably because Holmes was in the full stream of the New England intellectual tradition. That tradition means, above all else, intellectual independence and intellectual honesty. Holmes, the aristocrat who spoke as a denrocrat, was no more anomalous in New England than Oliver Wendell Holnes, Sr., than Emerson, than William or Henry James, than Brooks or Henry Adams. New England by tradition believes in ideas. The best of New Englanders are willing to follow those ideas wherever they nray lead. If there is any single clue to the complexity of Holmes, it is that from first to last he was a New England intellectual.

The letters to Pollock and Cohen provided the demonstration. Those letters are not first-rate literature. Holmes wrote nothing to threaten the preeminence of Walpole or Johnson, Swift or Chesterton. Sonie of the letters, moreover, could have been written by a self-conscious esthete primping himself in the mirror of a friend's eyes. But not all of them. Together they deinonstrate, not vanity, but a genuine zest for ideas. Holnies did not have the rarest of intellectual gifts, the ability to create intellectual systems, but he had in full ineasure the capacity to appreciate and to criticize the systems of others. And he had a never failing belief in the importance of intellectual endeavor. Plato, Sophocles, Butler, Aristotle, Dante, Bacon, Whitehead, Proust, Melville, Hegel, Haldane, Pascal, Bergson, Nietzsche, Saintsbury, Shakespeare, Rousseau, Tolstoi, Spengler, Russell, Flaubert-the list is endless and the attention to each quick and discerning.

His natural affinities were with the pragmatists. Even when he was most critical of James and his pragmatic notions, ${ }^{2}$ even when he dismissed all pragmatism as "hunıbug," he was never free from the

21 Holame-Porrock Letrers (Howe ed. 1941) 76, 100.

3 Id. at 163. 
pragmatic influence. Truth, he kept saying, was what he could not help believing. ${ }^{4}$ And although he was impatient with the James explanation of why men are compelled to their conclusions and more impatient with the James enthusiasm for the irrational and mysterious, Holmes, like his friend, believed in a world of sense and experience, a universe fundamentally pluralistic, full of cross currents and strife, largely indifferent to men and their quest for absolutes. Like many another amateur pragmatist he found in the imaginative skepticism of Santayana inuch to agree with. ${ }^{5}$

It was from this background of pragmatism, pluralism, and skepticism that Holmes approached the major creative effort of his life, his analysis of the common law. The conclusions he reached, better than anything else, explain his work on the Court. Here, as he toiled with the multiplicities and vagaries of judge-made law, he evolved the basic principles which were to control his judicial life.

He became, first of all, what has since been known as a legal realist, a lawyer disenchanted and disillusioned. Law, he concluded, is only a system for predicting judicial action:

The prophecies of what the courts will do in fact, and nothing more pretentious, are what I mean by the law. ${ }^{6}$

The object of our study, then, is prediction, the prediction of the incidence of the public force through the instrumentality of the courts. ${ }^{7}$

But, as I shall try to show, a legal duty so called is nothing but a prediction that if a man does or omits certain things he will be made to suffer in this or that way by judgment of the court; - and so of a legal right. ${ }^{8}$

Moreover, the law is largely amoral:

Moral predilections must not be allowed to influence our minds in settling legal distinctions. ${ }^{9}$

The first thing for a business-like understanding of the matter is to understand its limits, and therefore $I$ think it desirable at once to point out and dispel a confusion between morality and law, which sometimes rises to the height of conscious theory, and more often and

4 Id. at $99,126$.

5 Id. at 126,$260 ; 2$ id. 131.

6 The Path of the Law (1897) 10 HARv. L. REv. 457, 460-461.

$\tau I d$. at 457.

8 Id. at 458.

${ }^{2}$ The Coamron LAw (1881) 148. 
indeed constantly is making trouble in detail without reaching the point of consciousness. ${ }^{10}$

Manifestly, therefore, nothing but confusion of thought can result from assuming that the rights of man in a moral sense are equally rights in the sense of the Constitution and the law. ${ }^{11}$

For my own part, I often doubt whether it would not be a gain if every word of moral significance could be banished from the law altogether, and other words adopted which should convey legal ideas uncolored by anything outside the law. ${ }^{12}$

The duty to keep a contract at common law means a prediction that you must pay damages if you do not keep it, and nothing else. ${ }^{13}$

Finally, and this for present purposes is of first importance, he decided that the origin of law lies in the power of the majority to force its will upon the community:

It [legislation] is necessarily made a means by which a body, having the power, puts burdens which are disagreeable to them on the shoulders of somebody else. The more powerful interests must be more or less reflected in legislation; which, like every other device of man or beast, must tend in the long run to aid the survival of the fittest. ${ }^{14}$

The welfare of the individual is, therefore, a secondary concern:

Public policy sacrifices the individual to the general good. ${ }^{15}$

If this is a true account of the law as it stands, the law does undoubtedly treat the individual as a means to an end, and uses him as a tool to increase the general welfare at his own expense. ${ }^{16}$

If a man is on a plank in the deep sea which will only float one, and a stranger lays hold of it, he will thrust him off if he can. When the state finds itself in a similar position, it does the same thing. ${ }^{17}$

There is no difficulty in quarrelling with this view of the legal system. Legal literature for the past twenty-five years has been filled with the debate. The contestants, however, have too often ignored the practical aspect of the issue. They have tended to forget that a judge does more than recite opinions; he decides cases. Judicial scholarship becomes judgment; judicial theories become orders.

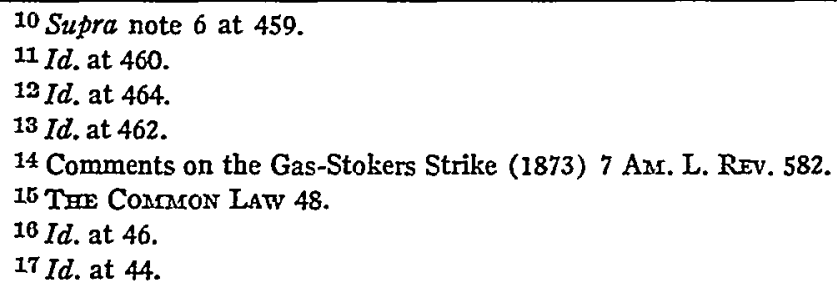


What then in terms of decision is the consequence of the view that law must "correspond with the actual feelmgs and demands of the community, whether right or wrong," 18 a view which tends to deny to the judge authority to be an affirmative force for a more decent society ${ }^{10}$ How will men fare with a constitutional theory which systematically sacrifices individual welfare to the need and the power of the community? Holmes nore than most judges was faithful to his principles. His decisions more than most decisions demonstrate the practical consequence of a legal creed strictly applied.

Certain unfortunate aspects of the Holmes position are well known. United Zinc Co. v. Britt ${ }^{20}$ is one illustration. Two children, camped with their parents near an unfenced tract of land, found an unguarded swimming pool in the basement of a demolished building. The water, as the landowner knew, was poisonous. The children died. The jury award of damages to the parents was satisfactory to Taft, Clarke and Day, because it was "calculated to make men more reasonably considerate of the safety of the children of their neighbors." Holmes for the Court reversed the verdict. The children, he pointed out, were trespassers. The nuisance, even if attractive, was not visible from the public way. ${ }^{21}$ These considerations, for him, disposed of the matter.

Aliens, with Holmes, sometimes had as little luck as the children. In American law immigrants are outlanders, entitled only to what Congress in its munificence is willing to grant. Here, if anywhere, the community rules supreme over the individual. Holmes pushed the logic relentlessly.

Ju Toy came to San Francisco from China, claiming American

18 Id. at 41 .

19 "But I go farther. There is no statute covering the case; there is no hody of precedent that by ineluctable logic requires the conclusion to which the court has come. The conclusion is reached by extending a certain conception of public policy to a new sphere. On such matters we are in perilous country." Holmes, J., dissenting in Dr. Miles Medical Co. v. Park \& Sons Co. (1911) 220 U. S. 373, 411.

" ... . but it also is true and not quite as tautologous as it seems, that the law knows nothing but legal rights." Holmes, J., in Denver v. Denver Union Water Co. (1918) 246 U.S. 178, 197.

"The law [an act of Congress] does not attempt to equalize fortune, opportunities or abilities." Holmes, J., dissenting in Interstate Com. Coinm. v. Diffenbaugh (1911) 222 U.S. $42,46$.

See also the dissenting opinions in B. \& W. Taxi Co. v. B. \& Y. Taxi Co. (1928) 276 U.S. 518, 532 and Panama R. R. Co. v. Rock (1924) 266 U.S. 209, 215.

20 (1922) 258 U. S. 268.

21 See also Holmes' famous stop, look and listen case, B. \& O. R.R. v. Goodman (1927) 275 U.S. 66. 
birth. The immigration officials, after a summary hearing, thought otherwise. On habeas corpus, the District Court agreed with Ju Toy and ordered his admission. But Holmes held that the administrative decision, right or wrong, was final. ${ }^{22}$ Brewer and Peckham found this "appalling." This, they said, amounted to banishment, a penalty of extreme hardship. Banishment for crime, they pointed out, could never come about except after the full process of the judicial system, mcluding consideration of the presumption of innocence. As long as the penalty remained the saine, there should be, they argued, the same protection, even though the question was place of birth rather than murder. ${ }^{23}$

In Ah How v. United States ${ }^{24}$ Holmes, again over dissent, sustained a statute making any failure of a Chmese to produce on demand a certificate of residence prima facie evidence of unlawful entry. And finally, in Keller v. United States ${ }^{25}$ Holmes argued for Congressional action which made it felonious for any person to harbor for immoral purpose any alien woinan within three years from the date she entered the United States. Here, however, the Court disagreed. The Court held that the statute had nothing to do with immigration, that it constituted an attempt by Congress to exercise state powers. Holmes thought otherwise. He argued that the practice of prostitution within three years after entry might be evidence of fraud upon the immigration law. Congress could, he said, punish the person who harbored the alien and who thus cooperated in the fraud. The commumity, in Holınes' judgment, was not only entitled to inake special rules for aliens but to create special crimes for all who were suffciently unwise to associate with them. ${ }^{26}$

22 United States v. Ju Toy (1905) 198 U.S. 253.

23 Conpare Brewer and Peckhan dissenting fron another Holmes decision, United States v. Sing Tuck (1904) 194 U.S. 161, 179: "I cast no reflections upon the inmigration oficer in the present case. I am simply challenging a system and provisions which place within the arbitrary power of an individual the denial of the right of an Anserican citizen to free entrance into this country, and put such denial outside the scope of judicial inquiry. It may be true that a ministerial officer, in a secret and private investigation, nay strive to ascertain the truth and to do justice, but unless we blind our eyes to the history of the long struggle in the nother country to secure protection to the liberty of the citizen, we must realize that a public investigation before a judicial tribunal, with the assistance of counsel and the privilege of cross-examination, is the best, if not the only, way to secure that result."

24 (1904) 193 U.S. 65.

25 (1909) 213 U.S. 138, 149.

${ }^{26}$ Like his tort decisions, Holmes' views on aliens have proved to be inadequate. $\mathrm{Ng}$ Fung Ho v. White (1922) 259 U.S. 276, limits the Ju Toy decision and holds that resident Chinese claiming citizenship cannot be deported without access to the courts. 
Many of the Holmes opinions in criminal law illustrate this same preoccupation with the power of the community and his less ardent regard for the plight of the individual. He would not, of course, permit a mob to substitute itself for a court, ${ }^{2 \pi}$ and he could on occasion rigidly circumscribe criminal statutes ${ }^{23}$ strictly limit the conspiracy rule, ${ }^{29}$ and argue for good sense in the rules of evidence. ${ }^{30}$ But, in general, his attitude is fairly illustrated by his remark in Kepner $v$. United States: ${ }^{31}$

At the present time in this country there is more danger that criminals will escape justice than that they will be subjected to tyranny.

There, against the Court, Holmes urged a narrow construction of the double jeopardy rule. He held, against dissent, in United States $v$. Holte, ${ }^{32}$ that a woman transported in white slavery could be guilty of conspiring to violate the statute. In Horning v. District of Colum$b i a^{33}$ he approved, over the objection of Brandeis, White, Day and McReynolds, a jury charge which was tantamount to a direction to find guilt. And neither the systematic practice of excluding certain classes of citizens from juries nor the failure of a committing magistrate to hear evidence of innocence seemed to him to raise substantial due process questions. ${ }^{34}$ Holmes, in Casey $v$. United States, ${ }^{35}$ sustained a criminal conviction which McReynolds, Brandeis, Butler and Sanford found unlawful, each on an independent ground. He agreed with White that twelve to twenty years imprisonment for a false entry in official records was not cruel or unusual pumshment. ${ }^{30}$ And, finally, in the wire tapping case itself, ${ }^{37}$ while Holmes was clear that the government should have no part of this "dirty business," it was on the

Bridges v. California (1941) 314 U.S. 252 demonstrates that a resident alien can invoke the First and Fiftl Amendments; and with Bridges v. Wixon (1945) 326 U.S. 135 the Court may have taken the first tentative step toward the proposition that the American Constitution provides equal and full protection to all men who feel the force of American sovereignty.

$2 \pi$ Moore v. Dempsey (1923) 261 U. S. 86.

28 United States v. Johnson (1911) 221 U.S. 488; Francis v. United States (1903) 188 U.S. 375.

29 Hyde v. United States (1912) 225 U.S. 347.

30 Donnelly v. United States (1913) 228 U. S. 243.

31 (1904) 195 U.S. 100, 134 (dissenting opinion).

32 (1915) 236 U.S. 140.

33 (1920) 254 U.S. 135.

34 Hughes v. Gault (1926) 271 U.S. 142; Rawlins v. Georgia (1906) 201 U.S. 638. 35. (1928) 276 U.S. 413.

36 Weems v. United States (1910) 217 U.S. 349, 382 (White, J., dissenting).

37 Olmstead v. Umited States (1928) 277 U.S. 438, 469 (dissenting opinion). 
ground "that the government should not play an ignoble part" rather than, as Brandeis thought, because of the constitutional immunity against unreasonable search and seizure and self-incrimination. ${ }^{38}$

Negroes found in Holmes no special pleader. His opinion in Nixon v. Herndon ${ }^{33}$ is unequivocal in denying Texas power to outlaw negro votes at a party primary. But his decision in Giles v. Harris ${ }^{40}$ and his dissent in Bailey v. Alabama $a^{41}$ are among the least notable pages in the Supreme Court reports.

Giles, an Alabama negro, wanted the Court to direct Alabama county officials to register the negroes as voters. Holmes, for the majority, thought the Court was helpless to grant relief, principally for the extraordinary reason that since Giles claimed the whole election scheme was fraudulent, he was in effect asking the Court to participate in the fraudulent arrangement. ${ }^{42}$ From this unhappy sophistry, Brewer, Brown and Harlan dissented. They thought, reasonably enough, that an American citizen did not forfeit his right to vote by complaining of the fraud which disenfranchised him.

Bailey, another Alabama negro, had better luck. ${ }^{43}$ Hughes, for the Court, held that an Alabama statute making it criminal to execute a contract of employment with an intent to defraud the employer established a system of peonage in violation of the Thirteenth Amendment when it also provided that failure to perform the contract service was prima facie evidence of the fraudulent intent. Holmes was unpersuaded. He saw no reason why fraudulent breach of a contract

38 It seems plain enough that the courts have an affirmative duty to improve and civilize the criminal law. If, as Holmes seemed to thmk, there is in that process some danger that criminals may go free, the answer must lie in improved crime detection, in prevention of juvenile delinquency and in elimination of the prejudice and poverty which lie at the root of crime. The problem can hardly be solved by sanctioning judicial practices of questionable fairness.

39 (1927) 273 U.S. 536.

40 (1903) 189 U.S. 475.

41 (1911) 219 U.S. 219, 245 (dissenting opinion).

42 Holmes said: "If then we accept the conclusion which it is the chief purpose of the bill to maintain, how can we make the court a party to the unlawful scheme by accepting it and adding another voter to its fraudulent lists? ... If we accept the plaintiff's allegations for the purposes of his case, he cannot complain. We must accept or reject them. It is impossible simply to shut our eyes, put the plaintiff on the lists, be they honest or fraudulent, and leave the determination of the fundamental question for the future. If we have an opinion that the bill is right on its face, or if we are undecided, we are not at liberty to assume it to be wrong for the purposes of decision. It seems to us that unless we are prepared to say that it is wrong, that all its principal allegations are immaterial and that the registration plan of the Alabama constitution is valid, we cannot order the plaintiff's name to be registered." (1903) 189 U.S. 475 at 486.

43 Bailey v. Alabama (1911) 219 U. S. 219 ; Bailey v. Alabama (1908) 211 U. S. 452. 
could not be made criminal and no reason why failure to perform the contract service could not be made presumptive evidence of fraudulent intent. The fact that the Alabama legislation would have done much to nullify all the gains in the struggle against slavery seemed to impress him not at all. The statute was, presumably, the will of the majority of Alabama citizens. He thought their wishes should be respected.

If devotion to the will of the majority led Holmes to dubious results in tort and criminal law and in considering the special problems of negroes and aliens, it provided him, in the area of government regulation, with enduring fame. Every free man owes gratitude to Holmes for his valiant struggle against the rule of the judges. The extent of his contribution can hardly be measured. He was the rallying point and the inspiration, the proof that the cause had respectability and integrity, the unfailing source of courage and faith in the ultimate victory. The cost to Holmes himself must have been considerable. For one thing, it must have been a lonely business. Holmes obviously preferred to agree with his associates. He had no ambition to shine at the expense of the Court; nor did he see any virtue in continuously msisting that the Court accept his view or hear his lengthy dissent. He was deeply conscious that the Court is not a committee of lawyers, that the Justices should, within the rigid limits of complete integrity, strive for a common ground of decision. Nevertheless, for more than twenty-five years, without hesitation or compromise, he stood by his faith. His dissents are not only classics of law; they are classics of courage. ${ }^{44}$ They merit, on that ground, unqualified admiration. The doctrine which they announce, however, is not so obviously beyond criticism.

Dissents are notoriously overstated, and a dissenter has little occasion to formulate his theories with exactness, but Holmes repeated his views with sufficient frequency to warrant the conclusion that he said no more than he meant. The most blunt statement is in Tyson \& Brother v. Banton: ${ }^{45}$

44 The list is, of course, familiar; Springer v. Philippine Islands (1928) 277 U.S. 189, 209; Louisville Gas Co. v. Coleman (1928) 277 U.S. 32, 41; Tyson \& Brother v. Banton (1927) 273 U.S. 418, 445; Frost Trucking Co. v. R. R. Com. (1926) 271 U.S. 583, 600; Weaver v. Palmer Bros. Co. (1926) 270 U.S. 402, 415 ; Adkins v. Children's Hospital (1923) 261 U. S. 525, 567 ; Truax v. Corrigan (1921) 257 U. S. 312, 342 ; Hammer v. Dagenhart (1918) 247 U.S. 251, 277; Coppage v. Kansas (1915) 236 U.S. 1, 26; Adair v. United States (1908) 208 U.S. 161, 190; Lochner v. New York (1905) 198 U.S. $45,74$.

45 (1927) 273 U.S. $418,446$. 
I think the proper course is to recognize that a state legislature can do whatever it sees fit to do unless it is restrained by some express prohibition in the Constitution of the United States or of the State, and that Courts should be careful not to extend such prohibitions beyond their obvious meaning by reading into them conceptions of public policy that the particular Court may happen to entertain.

This is unequivocal. It says that in American government the community may do as it pleases as long as it does not offend an express prohibition of the Constitution. Holmes was, of course, willing to concede that legislation beyond the bounds of reason was unconstitutional. ${ }^{47}$ But since he refused to consider the actual motives of the legislature $^{48}$ and was satisfied if he could imagine reasons for the legislation, ${ }^{49}$ it was a rare occasion indeed when the substantive as-

46 Equivalent language appears in Frost Trucking Co. v. R. R. Com. (1926) 271 U.S. 583, 601: "The only valuable significance of the much abused phrase police power is this power of the State to limit what otherwise would be rights having a pecuniary value, when a predominant public interest requires the restraint. The power of the State is limited in its turn by the constitutional guaranties of private rights, and it often is a dehicate matter to decide which interest preponderates and how far the State may go without making compensation."

See also: Truax v. Corrigan (1921) 257 U.S. 312, 344: "There is nothing that I more deprecate than the use of the Fourteenth Amendment beyond the absolute compulsion of its words to prevent the making of social experiments that an important part of the cominunity desires, in the insulated chambers afforded by the several States, even though the experiments may seem futile or even noxious to me and to those whose judgment I most respect."

Missouri, Kansas \& Texas Ry. Co. v. May (1904) 194 U. S. 267, 270: "Great constitutional provisions must be administered with caution. Some play must be allowed for the joints of the machine, and it must be remembered that legislatures are ultimate guardians of the hiberties and welfare of the people in quite as great a degree as the courts."

Liggett Co. v. Baldridge (1928) 278 U.S. 105, 115: "But for decisions to which I bow I should not think any conciliatory phrase necessary to justify what seems to me one of the incidents of legislative power."

47 See the Holmes dissents in Weaver v. Palmer Bros. Co. (1926) 270 U.S. 402, 415; Bartels v. Iowa (1923) 262 U.S. 404, 412; Adkins v. Children's Hospital (1923) 261 U.S. $525,567$.

48 Roschen v. Ward (1929) 279 U.S. 337, 339: "Of course we cannot suppose the Act to have been passed for sinister motives. We will assume that there are strong reasons against interference with the business as now done-but it is obvious that much good would be accomplished if eyes were examined in a great many cases where hitherto they have not been, and the balancing of the considerations of advantage and disadvantage is for the legislature not for the Courts. We cannot say, as the complainants would have us say, that the supposed benefits are a cloak for establishing a monopoly and a pretense."

49 E.g., Missouri, Kansas \& Texas Ry. Co. v. May (1904) 194 U. S. 267. 
pects of due process came into play..$^{50} \mathrm{He}$ was apparently content to make the legislature all powerful within the extremely wide limits of the express prohibitions of the Constitution. Property, on this analysis, has little constitutional protection except that it may not be taken for public use without payment of compensation. Liberty, in turn, has little protection except the specific guarantees of the bill of rights. The reservoir of sovereignty shifts from the people to the government.

The traditional idea of American government is quite different. Sovereiguty is said to reside in the people and, more precisely, in each individual. Every man is by definition free, free to do as he pleases unless there is a demonstrable necessity that his actions be controlled, a necessity demonstrable not only to the legislature but to the courts which interpret the Constitution which guards his freedom. The legislature, under this view, has no general authority. It has only a police power to be exercised in response to a plain public interest.

The old Court, misunderstanding this idea, abused it viciously. No one would today countenance a repetition of the decisions which provoked the famous dissents. But one need not be Holmes to avoid being Sutherland. The fact that the conventional idea was sadly abused does not necessarily mean that it should be totally abandoned. The question is substantial and fundamental. Shall the Court, by adopting the Holmes view, take most of the force from the notion of substantive due process? Is it faithful to the American tradition to declare that for most purposes there are virtually no limits on legislative action ${ }^{51}$

50 Perhaps it was for this reason that Holmes was sometimes surprisingly quick to find that property had been taken without payment of just compensation. Penna. Coal Co. v. Mahon (1922) 260 U.S. 393; Missouri Pacific Ry. v. Nebraska (1910) 217 U.S. 196; Louisville \& R. R. Co. v. Stock Yards Co. (1909) 212 U.S. 132. But see Holmes in Block v. Hirsh (1921) 256 U.S. 135; Denver v. Denver Union Water Co. (1918) 246 U.S. 178, 195 (dissenting opinion); Muhlker v. Harlem Railroad Co. (1905) 197 U.S. 544, 571 (dissenting opinion).

51 See Mr. Justice Peckham's statement of the problem in Lochner v. New York (1905) 198 U.S. 45, 56: "It must, of course, be conceded that there is a limit to the valid exercise of the police power by the State. There is no dispute concerning this general proposition. Otherwise the Fourteenth Amendment would have no efficacy and the legisIatures of the States would have unbounded power, and it would be enough to say that any piece of legislation was enacted to conserve the morals, the health or the safety of the people; such legislation would be valid, no matter how absolutely without foundation the claim might be. The claim of the police power would be a mere pretext-become another and delusive name for the supreme sovereignty of the state to be exercised free from constitutional restraint. This is not contended for. In every case that comes hefore this court, therefore, where legislation of this character is concerned and where the protection of the Federal Constitution is sought, the question necessarily arises: Is this a 
If history means anything, it seems evident that the men who drafted the Constitution had no such exalted notion of the legislature. They were suspicious of all power and their suspicion was only partly allayed because power was vested in a neighbor rather than a king. That suspicion, moreover, has much justification. No one who attends a session of the average state legislature can carry away the illusion that the people receive thoughtful or ardent representation. The percentage of state legislation adopted with the view to the welfare of the general public is infinitesimal. That legislation is usually created because special interests want it. The theory is regulation to protect the public. The fact, all too often, is regulation to protect the powerful. ${ }^{52}$

Consider, for example, Kotch v. Pilot Comm'rs. ${ }^{53}$ Louisiana has an elaborate system for the regulation of pilots and pilotage. That system mcludes a compulsory apprenticeship, the apprentices to be selected by the incumbent pilots. As might be expected, the pilots have displayed a marked preference for friends and relatives. This, it was argued, was an obvious violation of the Fourteenth Amendment. The

fair, reasonable and appropriate exercise of the police power of the State, or is it an unreasonably, unnecessary and arbitrary interference with the right of the individual to his personal liberty or to enter into those contracts in relation to labor which may seem to him appropriate or necessary for the support of himself and his family?"

52 There is no limit, these days, on the area within which state legislatures undertake to operate. In California, for example, the Business and Professions Code licenses and regulates the conduct of dentists, doctors, drug practitioners, chiropodists, mid-wives, nurses, optometrists, osteopaths, pharmacists, veterinarians, accountants, advertisers, architects, attorneys, barbers, civil engineers, collection agents, cosmetologists, detectives, funeral directors, embalmers, pest control operators, land surveyors, yacht brokers, ship brokers, real estate brokers, business opportunity brokers, cemetery brokers, brokers of oil and gas interests, itinerant merchants; it regulates automobiles, boxing and wrestling, furniture, bedding, horse-racing, paints, petroleum and second hand goods.

The Health and Safety Code has elaborate provisions concerning public health officers, clinics, maternity hospitals, rodents, rabies, mosquitoes, pest abatement, tuberculosis, drinking cups, towels, wiping rags, ice, garbage, refuse, water pollution, water supply, sewage, sanitation districts, dead bodies, embalming, disinterment, private cemeteries, public cemeteries, mausoleums, vital statistics, explosives, fireworks, fire prevention, fire equipment, hazardous weeds, housing, auto courts, trailer courts, yards, building heights, windows, fire escapes, airshafts, boiler rooms, garages, dormitories, bathtubs, sinks, showers, hotel bedding, exit signs, refrigerators, public meetings, swimming pools, tanks, boilers, excavation, convalescent colonies, drugs, foods and cosmetics.

And this is only the beginning. There is a separate and complete code for agriculture, for motor velicles, for insurance, for revenue and taxation, for welfare and institutions, for education, for politics and government, for public resources, for harbors and navigation, for fish and game, and for military and veterans. Finally, there are the general laws.

53 (1947) 330 U.S. 552. 
Court, over the dissent of Justices Rutledge, Reed, Douglas and Murphy, said no. To sustain this conclusion Mr. Justice Black wrote a typical Holmes opinion announcing a great deal of piety about the special problems of pilotage and concluding that the legislative judgment could not be said to be unreasonable. But surely no one can really believe that the ability to navigate is inherited. Certainly there is something fundamentally offensive to American government in permitting safety legislation to be used to create family monopolies.

This decision fairly illustrates the Holmes doctrine of deference to majority will, and the conclusion seems to follow that here as elsewhere Holmes represents an extreme position which should not be accepted. In the end, it may be for Brandeis, rather than Holmes, to provide guidance in problems of state and federal regulation. Holmes, believing that the legislature was largely entitled to do as it pleased, was quick to find reasons for the legislative judgment, and what he could not prove he could readily imagine. Brandeis was not so easily content. He realized that constitutional government names individual freedom as its highest ideal and, accordingly, that legislative encroachment on that freedom must be justified by substantial reasons. This does not contemplate, of course, an investigation into the actual motives of the members of the legislature. Nothing could be more futile. $^{54}$ But it does contemplate that the Court, without intruding the personal opinions of the Justices, shall accept only that legislation which has substantial, if mistaken, justification. ${ }^{.5}$ Our government is constitutional government and under our system the Constitution has only that strength which the Court gives to it. The people would not vote to repeal the Fourteenth Amendment; the Court should not repeal it for them. ${ }^{56}$

54. E.g., Powell, An Imaginary Judicial Opinion (1931) 44 HARv. L. REv. 889, and Macallen Co. v. Massachusetts (1929) 279 U.S. 620.

55 For differences in the Holmes and Brandeis techniques, compare their dissents in Louisville Gas Co. v. Coleman (1928) 277 U.S. 32; Myers v. United States (1926) 272 U.S. 52 ; Milwaukee Pub. Co. v. Burleson (1921) 255 U. S. 407; Eisner v. Macomber (1920) 252 U. S. 189. See also Internat'l News Serv. v. Asso. Press (1918) 248 U. S. 215.

56 Holmes' attention to the welfare of the community at the expense, if need be, of the welfare of the individual is reflected in his tax decisions. Double taxation offended, in his opinion, neither the Fourteenth Amendment nor the implications of the federal system. Baldwin v. Missouri (1930) 281 U.S. 586, 595 (dissenting opinion); Schlesinger v. Wisconsin (1926) 270 U. S. 230, 241 (dissenting opinion); Blackstone v. Miller (1903) 188. U.S. 189.

Only where the state lacked sovereignty did it, in bis judgment, lack the power to tax. Maxwell v. Bugbee (1919) 250 U. S. 525, 543 (dissenting opinion); Fargo v. Hart (1904) 193 U.S. 490. 
The vigor with which Holmes supported the rights of the community is equalled in his thought only by the vigor with which, in one area, he supported the rights of the individual. Holmes on free speech is whole-heartedly on the side of individual freedom. ${ }^{5 \pi}$ This deviation from the customary pattern is easy to understand. Holmes' schooling in free speech did not come from the common law or from pragmatism. It came from the intellectual tradition of man. On this issue Holmes spoke, not as the student of Blackstone, Coke, and Kent, but as the pupil and successor of Milton, Voltaire, and Jefferson. $\mathrm{He}$ spoke, moreover, as one fully worthy of that distinguished fellowship. Holmes, like other judges, was entirely human and beneath and beyond the jurist was the student of ideas, who, elsewhere preserving his skepticism, never seriously doubted the importance of intellectual accomplishment. This he found more enduring and more fundamental than realism in law, than experiments in politics. Holmes received his learning from the great men of history. Like any thoughtful man thus educated, he was most anxious that all men should learn and think and have their say. With this principle he would tolerate no experimentation. Here there was no good natured deference to the community's mistaken belief in censorship and suppression. Holmes' loyalty to free speech and free thought was as rigid and unyielding

The major problem of federal government, the problem of reconciling federal and state power, was for Holmes the problem of deciding between two expressions of the community will. It therefore became, as he said so often, the problem of drawing a line. His decisions are, of course, on both sides of that line. No one was more willing to grant to the federal governnent full power to represent the nation and to sustain itself. Sanitary District v. United States (1925) 266 U.S. 405 ; Johnson v. Maryland (1920) 254 U.S. 51 ; Missouri v. Holland (1920) 252 U.S. 416; Hammer v. Dagenhart (1918) 247 U.S. 251, 277 (dissenting opinion). But Holmes was not insensitive to the needs of the states and he was unwilling to allow the federal government, its instrumentalities or einployees, any immunity from state sovereignty unjustified by the practical necessities of the federal system. The wirole trend of modern law on state taxation of interstate commerce finds its clearest expression in the Holmes epigram "The power to tax is not the power to destroy while this Court sits," Panhandle Oil Co. v. Knox (1928) 277 U.S. 218, 223 (dissenting opinion); and he has many decisions that illustrate his point. See, for example, Gulf, Colorado \& Ry. v. Texas (1918) 246 U. S. 58; Western Union Tel. Co. v. Kansas (1910) 216 U.S. 1, 52 (dissenting opinion).

57 United States v. Schwimmer (1929) 279 U.S. 644, 653 (dissenting opinion); Whitney v. California (1927) 274 U.S. 357, 372 (Brandeis, J., concurring); Gitlow v. New York (1925) 268 U.S. 652, 672 (dissenting opinion); Craig v. Hecht (1923) 263 U.S. 255, 280 (dissenting opinion); Milwaukee Pub. Co. v. Burleson (1921) 255 U.S. 407, 436 (dissenting opinion); Abrams v. United States (1919) 250 U. S. 616, 624 (dissenting opinion); Debs v. United States (1919) 249 U.S. 211; Frohwerk v. United States (1919) 249 U. S. 204; Schenck v. United States (1919) 249 U. S. 47 ; Toledo Newspaper Co. v. United States (1918) 247 U. S. 402, 422 (dissenting opinion). 
and as arrogant as the judicial bigotry which elsewhere he so vigorously condemned.

Thus it turns out that Holmes leaves with the student of law and govermnent a question rather than an answer. In general, he was on the side of majority power. In general that position served him and the nation well. But not always. Aliens, those accused of crime, $\mathrm{Ne}$ groes and other minorities deserve from the law better treatment than Holmes gave them. And Holmes himself, when freedom of speech, and thought was at issue, deserted the pattern of his faith. The doctrime he bequeathed to us requires for our time dispassionate appraisal. Most of all it needs to be divorced from sanctity. This is not an act of impudence. Holmes less than any man would approve adulation of his words or his person. He would have us look at our world closely. If what we find there requires less attention to the rights of the majority and more effort to protect the individual than he provided, he would be the first to say get on with it. 